\title{
PENERAPAN MODEL PEMBELAJARAN GENERATIF DENGAN SETTING KELAS KOOPERATIF STAD (STUDENT TEAM ACHIEVEMENT DIVISION) UNTUK MENINGKATKAN PEMAHAMAN KONSEP KIMIA DAN KINERJA ILMIAH SISWA KELAS X MIPA 7 SMA NEGERI 5 DENPASAR TAHUN PELAJARAN 2016/2017
}

\author{
A.A. Rai Miyati \\ SMA Negeri 5 Denpasar \\ Email:raimiyati_sma5dps@gmail.com
}

\begin{abstract}
ABSTRAK
Penelitian tindakan kelas ini bertujuan untuk: 1) meningkatkan pemahaman konsep kimia, dan 2) meningkatkan kinerja ilmiah siswa dalam pembelajaran kimia pada pokok bahasan larutan elektrolit non elektrolit dan reaksi aksidasi reduksi. Penelitian ini melibatkan 36 siswa kelas X MIPA 7 SMA Negeri 5 Denpasar. Objek penelitian ini adalah: 1) pemahaman konsep kimia siswa, 2) dan kinerja ilmiah siswa. Data pemahaman konsep kimia siswa dikumpulkan dari tes pemahaman konsep, kemudian dianalisis. Penelitian dikatan berhasil jika rata-rata pemahaman konsep siswa lebih besar atau sama dengan 75, DSS $\geq 75 \%$ dan $\mathrm{KK} \geq 85 \%$. Data aspek kinerja ilmiah siswa dikumpulkan dengan rubrik penilaian kinerja ilmiah. Data dianalisis dengan menggunakan kriteria mean ideal. Penelitian dikatan berhasil jika secara kualitatif kinerja ilmiah siswa berkategori tinggi. Hasil analisis menunjukkan: (1) Penerapan model pembelajaran generatif dengan seting kelas kooperatif STAD dapat meningkatkan pemahaman konsep kimia siswa kelas X MIPA 7 SMA Negeri 5 Denpasar Tahun Ajaran 2016/2017. Hal ini terlihat dari nilai rata-rata pemahaman konsep siswa sebesar 76,30 dan ketuntasan klasikalnya 72,22\% . Daya serap siswa adalah sebesar 76,30\% dengan standar deviasi 7,88 meningkat pada siklus II sebesar 84,07 dengan ketuntasan klasikalnya mencapai $94,44 \%$. Daya serap siswa pada siklus II adalah sebesar $84,07 \%$ dengan standar deviasi 5,58; (2) Penerapan model pembelajaran generatif dengan seting kelas kooperatif STAD dapat meningkatkan kinerja ilmiah siswa kelas X MIPA 7 SMA Negeri 5 Denpasar Tahun Ajaran 2016/2017. Hal ini terlihat dari nilai rata-rata kinerja ilmiah siswa pada siklus I sebesar 52,56 dengan standar deviasi 14,76 yang berada pada kategori kurang tinggi meningkat pada siklus II menjadi 71,36 dengan standar deviasi 10,89 yang berada pada kategori tinggi. Kinerja ilmiah siswa mengalami peningkatan dari siklus I ke siklus II sebesar $35,77 \%$.
\end{abstract}

Kata Kunci : pembelajaran generatif, kooperatif STAD, pemahaman konsep, kinerja ilmiah

\section{ABSTRACT}

This classroom action research aims to: 1) improve understanding of chemical concepts, and 2) improve scientific performance of students in chemistry learning on the subject of non electrolyte electrolyte solutions and reduction oxidation reactions. This study involved 36 students of class X MIPA 7 Denpasar Senior High School 5. The object of this research are: 1) understanding of students 'chemical concepts, 2) and students' scientific performance. Data on understanding students' chemical concepts is collected from concept understanding tests, then analyzed. The research is successful if the average conceptual understanding of students is greater or equal to 75, DSS S 75\% and KK KK 85\%. Data on students' scientific performance aspects are collected with a scientific performance 
assessment rubric. Data were analyzed using ideal mean criteria. The research is successful if qualitatively the scientific performance of students is high. The results of the analysis show: (1) The application of the generative learning model with the STAD cooperative class settings can improve the understanding of the chemical concepts of class X MIPA 7 Denpasar Senior High School 5 Academic Year 2016/2017. This can be seen from the average value of students' concept understanding of 76.30 and classical completeness of $72.22 \%$. Student absorption is $76.30 \%$ with a standard deviation of 7.88 increasing in the second cycle of 84.07 with classical completeness reaching $94.44 \%$. The absorption of students in the second cycle was $84.07 \%$ with a standard deviation of 5.58; (2) The application of the generative learning model with the STAD cooperative class setting can improve the scientific performance of class X MIPA 7 Denpasar Senior High School 5 Academic Year 2016/2017. This can be seen from the average value of scientific performance of students in the first cycle of 52.56 with a standard deviation of 14.76 which is in the low category increased in the second cycle to 71.36 with a standard deviation of 10.89 which is in the high category. Scientific performance of students has increased from cycle I to cycle II by $35.77 \%$.

Keywords: Generative learning, Cooperative STAD, Understanding concepts, Scientific performance

\section{PENDAHULUAN}

Pendidikan adalah salah satu faktor terpenting dalam menentukan kualitas sumber daya manusia di suatu negara. Memasuki era global seperti sekarang ini, perubahan besar telah terjadi di dunia, hal ini salah satunya dapat dilihat dengan adanya kemajuan dalam bidang ilmu pengetahuan dan teknologi (IPTEK). Dalam kemajuan IPTEK tersebut, pendidikan memegang peranan penting dalam kehidupan. Untuk dapat bersaing dalam dunia global, maka pendidikan yang memegang peranan penting tersebut, mutunya haruslah ditingkatkan.

Banyak langkah yang telah dilakukan oleh pemerintah dalam upaya meningkatkan mutu dan kualitas pendidikan, salah satunya adalah revisi kurikulum secara berkesinambungan. Kurikulum yang telah diterapkan sekarang yaitu Kurikulum Tingkat Satuan Pendidikan (KTSP) merupakan penyempurnaan dari Kurikulum Berbasis Kompetensi (KBK), dengan harapan tujuan pendidikan nasional akan tercapai. Selain itu, pemerintah juga telah melakukan program musyawarah guru bidang studi, penataran kerja guru, hingga proyek peningkatan kualifikasi guru dan dosen. Semuanya ini dimaksudkan untuk meningkatkan sumber daya manusia dari segi tenaga pengajarnya. Namun demikian, akhir-akhir ini pendidikan di Indonesia masih menjadi sorotan karena kualitas dan mutunya yang masih rendah. Hal ini dapat dilihat dari rangking Indonesia menurut laporan United Nations Educational, Scientific and Cultural Organization (UNESCO) yang berada pada urutan 62 dari 130 negara di dunia (Samhadi, 2007).

Hal tersebut menunjukkan bahwa banyaknya upaya dan langkah yang ditempuh pemerintah dalam meningkatkan kualitas pembelajaran belum diikuti oleh hasil yang memuaskan seperti apa yang diharapkan. Berdasarkan hasil observasi di SMA Negeri 5 Denpasar, didapatkan hasil belajar siswa yang terdiri atas pemahaman konsep dan kinerja ilmiah siswa. Berdasarkan pedoman pelaksanaan proses belajar mengajar dan penilaian yang ditetapkan di SMA Negeri 5 Denpasar, siswa dikatakan tuntas secara individu 
apabila memperoleh nilai $\geq 75$, sedangkan untuk kelas dikatakan tuntas apabila mencapai ketuntasan klasikal $(\mathrm{KK}) \geq 85 \%$.

Berdasarkan uraian tersebut di atas, sebagai upaya meningkatan hasil belajar siswa, maka peneliti menerapkan pembelajaran inovatif model generatif yang dikombinasikan dengan setting kelas kooperatif STAD dalam pembelajaran kimia melalui penelitian yang berjudul "Penerapan Model Pembelajaran Generatif Dengan Setting Kelas Kooperatif STAD (Student Team Achievement Division) Untuk Meningkatkan Pemahaman Konsep Kimia Dan Kinerja Ilmiah Siswa Kelas X MIPA 7 SMA Negeri 5 Denpasar Tahun Ajaran 2016/2017'.

Berdasarkan latar belakang tersebut, maka dapat dirumuskan permasalahan yang akan menuntun dalam pelaksanaan penelitian ini adalah :

1) Apakah penerapan model pembelajaran generatif dengan setting kelas kooperatif STAD dapat meningkatkan pemahaman konsep kimia siswa kelas $\mathrm{X}$ MIPA 7 SMA Negeri 5 Denpasar Tahun Ajaran 2016/2017?

2) Apakah penerapan model pembelajaran generatif dengan setting kelas kooperatif STAD dapat meningkatkan kinerja ilmiah siswa kelas $\mathrm{X}$ MIPA 7 SMA Negeri 5 Denpasar Tahun Ajaran 2016/2017 dalam pembelajaran kimia?

Tujuan yang ingin dicapai melalui penelitian ini adalah:

1) Meningkatkan pemahaman konsep siswa kelas X MIPA 7 SMA Negeri 5 Denpasar Tahun Ajaran 2016/2017 melalui penerapan model pemebelajaran generatif dengan setting kelas STAD dalam pembelajaran kimia.

2) Meningkatkan kinerja ilmiah siswa kelas X MIPA 7 SMA Negeri 5 Denpasar Tahun Ajaran 2016/2017 melalui penerapan model pemebelajaran generatif dengan setting kelas STAD pembelajaran kimia.

Sains (IPA) pada hakikatnya memiliki dua dimensi yaitu sebagai produk dan sebagai proses (Sadia, 1998). Sains merupakan kumpulan pengetahuan yang meliputi fakta-fakta, konsep-konsep, prinsip-prinsip, dan teori-teori yang disebut produk sains, dan sains sebagai keterampilan-keterampilan dan sikap-sikap yang dibutuhkan untuk memperoleh dan mengembangkan pengetahuan yang disebut proses sains. Sains sebagai produk dan sebagai proses bukanlah merupakan dua dimensi yang terpisah, namun merupakan dua dimensi yang terjalin erat sebagai satu kesatuan dan memiliki penekanan yang seimbang. Proses sains akan menghasilkan pengetahuan (produk) sains yang baru, dan pengetahuan sebagai produk sains akan memunculkan pertanyaan baru untuk diteliti melalui proses sains sehingga dihasilkan pengetahuan (produk) yang lebih baru lagi. Proses sains adalah proses ilmiah yang didalamnya terdapat prosedur pemecahan masalah melalui metode ilmiah; metode ilmiah meliputi observasi, perumusan masalah, penyusunan hipotesis, perancangan eksperimen atau percobaan, evaluasi, pengukuran, dan penarikan kesimpulan. Sedangkan produk ilmiah merupakan kumpulan pengetahuan yang berupa fakta, konsep, prinsip, teori dan hukum mengenai gejala alam.

Model pembelajaran merupakan sebuah rencana atau pola yang mengorganisasi 
pembelajaran dalam kelas dan menunjukkan cara penggunaan materi pembelajaran (Tika, 2005). Model belajar mengajar mempunyai makna yang lebih luas daripada strategi, metode, ataupun prosedur. Model pengajaran mencakup suatu pendekatan pengajaran yang luas dan menyeluruh. Lebih lanjut bahwa satu model pengajaran tersebut dapat menggunakan sejumlah keterampilan metodologis dan prosedural, seperti merumuskan masalah, mengemukakan pertanyaan, melakukan penelitian, berdiskusi, dan memperdebatkan temuan, bekerja secara kolaboratif, menciptakan karya seni, dan melakukan presentasi (Tika, 2005).

Dalam Suastra (2006), disebutkan model pembelajaran generatif adalah model pembelajaran yang berlandas-kan pada pandangan konstruktivisme dalam belajar mengajar yaitu pandangan yang berpedoman pada asumsi dasar bahwa pengetahuan dibangun dalam pikiran pebelajar. Mardana, et al.,(2001) dan Kemenuh (2005) menyebutkan model pembelajaran generatif bertolak dari pemikiran-pemikiran bahwa: 1) siswa memiliki ide awal tentang sains sebelum mereka memperoleh pembelajaran formal; 2) siswa tidak menerima secara pasif makna dari konsep sains tetapi mengkontruksi makna itu secara aktif; 3) makna tersebut diuji jika makna itu membuat pemahaman yang sesuai dengan penilaiannya maka makna tersebut masuk dalam memori siswa; 5) pembelajaran akan bermakna jika pebelajar mengganti memorinya dengan makna ilmiah baru yang terkontruksi. Dalam model pembelajaran generatif ini, siswa sendirilah yang lebih aktif secara mental membangun pengetahuannya. Sedangkan peranan guru dalam hal ini adalah hanya sebagai fasilitator dan mediator. Model belajar generatif merupakan salah satu model belajar yang dapat diterapkan untuk mengubah konsep (conceptual change) (Sugiarta, 2003). Dengan kata lain model ini dapat pula diterapkan untuk meningkatkan pemahaman konsep siswa.

Pembelajaran kooperatif merupakan strategi pembelajaran dalam kelompok kecil yang bekerja bersama-sama untuk memaksimalkan penguasaan tentang apa yang dipelajari oleh siswa. Di dalam kelas kooperatif tersebut, kelompok kecil yang dimaksud terdiri dari siswa yang sederajat tetapi heterogen, kemampuan, jenis kelamin, suku/ras, dan satu sama lain saling membantu. Tujuan dibentuknya kelompok tersebut adalah untuk memberikan kesempatan kepada semua siswa untuk dapat terlibat secara aktif dalam proses berpikir dan kegiatan belajar. Dalam pembelajaran kooperatif terjadi proses saling membantu di antara anggotaanggota kelompok. Pembelajaran kooperatif muncul dari konsep bahwa siswa akan lebih mudah menemukan dan memahami konsep yang sulit jika mereka saling berdiskusi dengan temannya (Setiawan, 2005). Pembelajaran kooperatif ini disusun dalam sebuah usaha untuk meningkatkan partisipasi siswa, memfasilitasi siswa dengan pengalaman sikap kepemimpinan dan membuat keputusan dalam kelompok serta memberikan kesempatan pada siswa untuk berinteraksi dan belajar bersama-sama siswa yang berbeda latar belakangnya (Triatno, 2007). Dengan bekerja secara kolaboratif untuk mencapai sebuah tujuan bersama, maka siswa akan mengembangkan keterampilan berhubungan dengan sesama manusia yang akan sangat bermanfaat bagi kehidupan di luar sekolah. 


\section{METODE PENELITIAN}

Jenis penelitian ini adalah penelitian tindakan kelas (PTK). Penelitian ini dilaksankan bulan Januari sampai dengan Juni 2017. Subjek dalam penelitian ini adalah semua siswa kelas X MIPA 7 SMA Negeri 5 Denpasar yang berjumlah 36 orang. Objek penelitian tindakan kelas ini adalah: 1) pemahaman konsep kimia, dan 2) kinerja ilmiah siswa kelas $X$ MIPA 7 SMA Negeri 5 Denpasar. Desain PTK ini dapat dilihat pada Gambar 1.

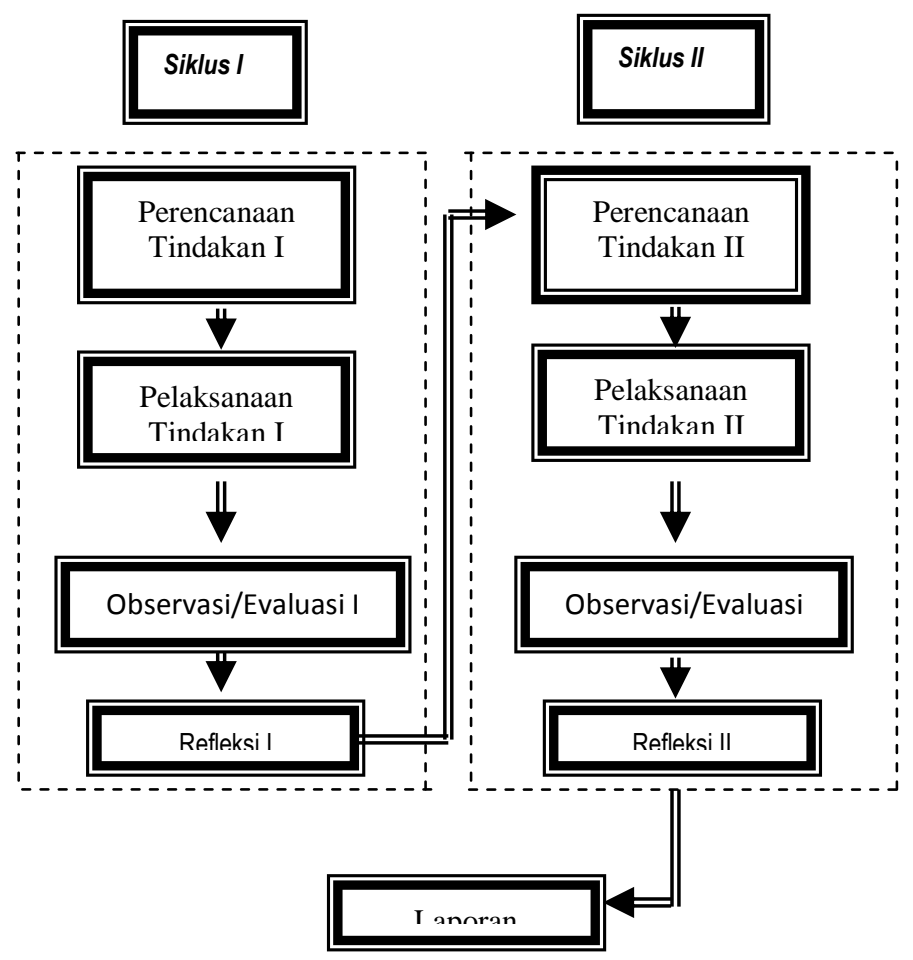

Gambar 1. Rancangan Penelitian Tindakan Kelas

Data pemahaman konsep siswa dianalisis secara deskriptif yang diperoleh melalui tes pemahaman konsep. Tes pemahaman konsep yang diberikan pada setiap akhir pokok bahasan (akhir siklus) adalah berupa pilihan ganda sebanyak 15 soal. Jika siswa benar mendapat poin 1, jika siswa salah mendapat poin 0 . skor siswa kemudian dikonversi ke dalam skala 100 melalui persamaan:

$$
X=\frac{\text { skor perolehan }}{\text { skor maksimum }} \times 100
$$

Berdasarkan nilai pemahaman konsep siswa, selanjutnya dicari nilai ratarata pemahaman konsep siswa $(\overline{\mathrm{X}})_{p k}$ dengan rumus:

$$
\bar{X}_{\mathrm{pk}}=\frac{\sum \mathrm{X}}{\mathrm{N}}
$$

(Diadaptasi dari Arikunto, 2003:371) Keterangan:

$\sum \mathrm{X}=$ jumlah nilai pemahaman konsep siswa

$\mathrm{N}=$ jumlah siswa

$\overline{\mathrm{X}}_{\mathrm{pk}}=$ nilai rata-rata pemahaman konsep siswa

Adapun ketuntasan pemaham-an konsep siswa dapat ditentukan dengan menggunakan daya serap siswa (DSS) dan ketuntasan klasikal (KK).

DSS $=\frac{\text { Nilai y angdicapai siswa }}{\text { Nilai maksimum }} \times 100 \%$
KK $=\frac{\text { Bany aksiswa y angtuntas }}{\text { Jumlah siswa }} \times 100 \%$

Kriteria yang digunakan adalah, siswa dikatakan tuntas jika DSS $\geq 75 \%$ dan satu kelas di katakan tuntas jika $\mathrm{KK} \geq$ $85 \%$. Hal ini sesuai dengan kriteria yang ditetapkan oleh SMA Negeri 5 Denpasar. Penelitian dikatakan berhasil jika nilai rata-rata pemahaman konsep siswa $\left(\overline{\mathrm{X}}_{p k}\right)$ $\geq 75$ dan ketuntasan klasikal $(\mathrm{KK}) \geq 85 \%$.

Data kinerja ilmiah siswa dianalisis secara deskriptif berdasarkan skor rata-rata $(\bar{X})$, mean ideal (MI), dan standar deviasi ideal (SDI). Data nilai kinerja siswa tersebut dikumpulkan tiap pertemuan dengan menggunakan lembar observasi. kinerja ilmiah siswa yang di observasi dalam pembelajaran terdiri atas 6 item lembar observasi dan masing-masing item 
terdiri dari 5 kriteria. Berdasarkan hal tersebut dapat ditentukan skor tertinggi ideal adalah 30 dan skor terendah ideal adalah 6. Skor ini kemudian dikonversi ke skala seratus melalui persamaan:

$X=\frac{\text { skor perolehan }}{\text { skor maksimum }} \times 100$

Nilai maksimum yang mampu dicapai siswa dalah 100 dan nilai minimumnya adalah 20 .

Penggolongan kinerja siswa ditetapkan berdasarkan lima jenjang kategori seperti pada Tabel 1.

Tabel 1. Kriteria Penggolongan Kinerja

\begin{tabular}{|c|c|c|}
\hline No & Kriteria & Kategori \\
\hline & $\overline{\mathrm{X}}_{k i} \geq \mathrm{MI}+1,5$ & Sangat Tinggi \\
\hline 2 & $\begin{array}{l}\mathrm{MI}+0,5 \text { SDI } \leq \\
\overline{\mathrm{X}}_{k i}<\mathrm{MI}+1,5 \mathrm{SDI}\end{array}$ & Tinggi \\
\hline 3 & $\begin{array}{c}\mathrm{MI}-0,5 \text { SDI } \leq \\
\overline{\mathrm{X}}_{k i}<\mathrm{MI}+0,5 \mathrm{SDI}\end{array}$ & Cukup Tinggi \\
\hline 4 & $\begin{array}{l}\mathrm{MI}-1,5 \mathrm{SDI} \leq \overline{\mathrm{X}}_{k i} \\
<\mathrm{MI}-0,5 \mathrm{SDI}\end{array}$ & Kurang Tinggi \\
\hline 5 & $\overline{\mathrm{X}}_{k i}<\mathrm{MI}-1,5 \mathrm{SDI}$ & $\begin{array}{l}\text { Sangat Kurang } \\
\text { Tinggi }\end{array}$ \\
\hline
\end{tabular}

(Dimodifikasi dari Nurkancana \&

Sunartana, 1990)

Keterangan:

Rumusan untuk MI dan SDI adalah :

MI $=1 / 2$ (skor tertinggi + skor terendah $)$

$\mathrm{SDI}=1 / 6$ (skor tertinggi - skor terendah $)$

$$
\overline{\mathrm{X}}_{k i}=\frac{\sum \mathrm{X}}{\mathrm{N}}
$$

(Dimodifikasi dari Arikunto, 2003:371)

Keterangan:

$\sum X=$ jumlah skor kinerja siswa

$\mathrm{N}=$ jumlah siswa

$\overline{\mathrm{X}}_{k i}=$ nilai rata-rata kinerja siswa

Perhitungan mean ideal (MI) dan

simpangan baku ideal (SDI) adalah sebagai berikut.

MI $=1 / 2$ (skor tertinggi ideal + skor terendah ideal)

$$
=1 / 2(100+20)=60
$$

SDI $=1 / 6$ (skor tertinggi ideal - skor terendah ideal)

$$
=1 / 6(100-20)=13
$$

Pedoman penggolongan kinerja siswa dapat dilihat pada Tabel 2.

Tabel 2. Kategori Penggolongan Kinerja

\begin{tabular}{cll}
\multicolumn{3}{c}{ Siswa } \\
\hline No & Kriteria & Kategori \\
\hline 1 & $\overline{\mathrm{X}}_{k i} \geq 80$ & Sangat \\
& $67 \leq \overline{\mathrm{X}}_{k i}<$ & Tinggi \\
2 & Tinggi \\
& 80 & \\
3 & $53 \leq \overline{\mathrm{X}}_{k i}<$ & Cukup \\
& 67 & Tinggi \\
4 & $40 \leq \overline{\mathrm{X}}_{k i}<$ & Kurang \\
& 53 & Tinggi \\
& & Sangat \\
5 & $\overline{\mathrm{X}}_{k i}<40 \quad$ Kurang \\
& & Tinggi \\
\hline
\end{tabular}

Penelitian tindakan kelas ini dikatakan berhasil apabila nilai rata-rata kinerja siswa minimal berada pada kategori tinggi. Nilai rata-rata kinerja siswa yang diperoleh dari perhitungan dibandingkan dengan kategori penggolongan yang telah ditetapkan.

\section{HASIL DAN PEMBAHASAN}

Deskripsi Proses Pembelajaran Siklus I

Penelitian tindakan kelas ini dilaksanakan di kelas X MIPA 7 SMA Negeri 5 Denpasar pada tahun ajaran 2016/2017 dengan subjek penelitian berjumlah 36 orang. Materi yang dibahas pada siklus I adalah larutan elektrolit dan larutan non elektrolit. Pelaksanaan siklus I terdiri dari tiga kali pertemuan tatap muka dan satu kali pertemuan untuk pemberian tes pemahaman konsep kimia pada siswa. Dalam seminggu, siswa mendapatkan pelajaran kimia sebanyak satua kali dengan alokasi waktu setiap pertemuan adalah 2 jam pelajaran atau 90 menit. 
Sebaran frekuensi data pemahaman konsep siswa siklus I disajikan pada Gambar 2.

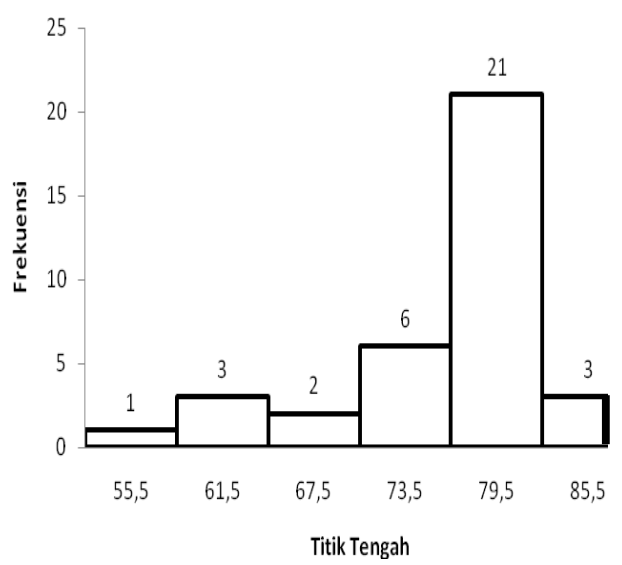

Gambar 2. Pemahaman konsep siswa siklus I

Persentase pemahaman konsep siswa pada akhir siklus I untuk masingmasing kategori dapat dilihat pada Tabel 3.

Tabel 3. Ketuntasan belajar siswa siklus I

\begin{tabular}{ccccc} 
Kategori & $\begin{array}{c}\text { Jml } \\
\text { siswa }\end{array}$ & $\%$ & DSS & KK \\
\hline Tuntas & 24 & $66,67 \%$ & & \\
Tidak & 12 & $33,33 \%$ & $76,30 \%$ & $72,22 \%$ \\
Tuntas & & & & \\
\hline
\end{tabular}

Berdasarkan hasil analisis data pemahaman konsep siswa pada siklus I diperoleh rata-rata sebesar 76,30 dengan daya serap $76,30 \%$ dan standar deviasi 7,88 serta dengan tingkat ketuntasan klasikal sebesar 72,22\%. Kategori keberhasilan penelitian adalah jika nilai rata-rata siswa lebih besar atau sama dengan 75, daya serap siswa lebih besar atau sama dengan $75 \%$ dan ketuntasan klasikal siswa lebih besar atau sama dengan $85 \%$. Berdasarkan data nilai pemahaman konsep siswa pada siklus I, maka penelitian ini belum memenuhi syarat keberhasilan tersebut. Hal ini karena berdasarkan kategori yang telah ditetapkan.

Untuk penilaian kinerja ilmiah siswa pada siklus 1 dapat dilihat pada Tabel 4.

Tabel 4. Perbandingan rata-rata kinerja ilmiah siswa siklus I

\begin{tabular}{lccc}
\hline \multirow{2}{*}{ Variabel Data } & \multicolumn{3}{c}{ Pertemuan Siklus I } \\
& I & II & III \\
\hline Rata-rata & 51,67 & 52,78 & 53,24 \\
Standar Deviasi & 16,84 & 13,95 & 13,67 \\
Skor Maksimum & 80 & 77 & 77 \\
Skor Minimum & 27 & 30 & 30 \\
Kualifikasi & KT & KT & CT \\
\hline
\end{tabular}

Untuk mengetahui kualifikasi data kinerja ilmiah siklus I disajikan pada Tabel 5 berikut.

Tabel 5. Kualifikasi data kinerja ilmiah siklus I

\begin{tabular}{|c|c|c|c|c|}
\hline No & Kriteria & Kategori & $\begin{array}{c}\text { Fre- } \\
\text { kuensi }\end{array}$ & $\begin{array}{c}\text { Persentase } \\
(\%)\end{array}$ \\
\hline 1 & $X \geq 80$ & $\begin{array}{l}\text { Sangat } \\
\text { Tinggi }\end{array}$ & 0 & $0,00 \%$ \\
\hline 2 & $\begin{array}{c}67 \geq X \\
<80 \\
53>X\end{array}$ & Tinggi & 10 & $27,78 \%$ \\
\hline 3 & $\begin{array}{c}<67 \\
40 \geq X\end{array}$ & $\begin{array}{l}\text { Tinggi } \\
\text { Kurang }\end{array}$ & 5 & $13,89 \%$ \\
\hline 4 & $<53$ & $\begin{array}{l}\text { Tinggi } \\
\text { Sangat } \\
\text { Kurang }\end{array}$ & 13 & $36,11 \%$ \\
\hline 5 & $X<40$ & Tinggi & 8 & $22,22 \%$ \\
\hline \multicolumn{4}{|c|}{ Rata-rata } & 52,56 \\
\hline \multicolumn{4}{|c|}{ Standar Deviasi } & 14,76 \\
\hline \multicolumn{4}{|c|}{ Skor Maksimum } & 78 \\
\hline \multicolumn{4}{|c|}{ Skor Minimum } & 29 \\
\hline \multicolumn{4}{|c|}{ Kualifikasi } & KT \\
\hline
\end{tabular}

Berdasarkan hasil analisis data kinerja ilmiah siswa, diperoleh rata-rata kinerja ilmiah siswa $\left(\overline{\mathrm{X}}_{k i}\right)$ sebesar 52,56 dengan standar deviasi 14,76. Berdasarkan kriteria penggolongan kinerja ilmiah siswa yang telah ditetapkan, kinerja ilmiah siswa kelas 
X MIPA 7 SMA Negeri 5 Denpasar pada siklus I berada pada kategori Kurang Tinggi.

\section{Deskripsi Proses Pembelajaran Siklus II}

Secara garis besar, pelaksanaan proses pembelajaran pada siklus II sama dengan siklus I, namun pelaksanaan tindakannya disesuaikan dengan hasil refleksi siklus I. Pelaksanaan kegiatan pembelajaran pada siklus II dibagi menjadi tiga pertemuan tatap muka dan satu kali pertemuan untuk tes akhir siklus II. Materi yang dikaji pada siklus II ini adalah reaksi redoks. Tahapan penelitian di siklus II sama seperti pada siklus I.

Adapun hal-hal yang disiapkan dan hasil dati tahap persiapan siklus II adalah sebagai berikut.

a) Merumuskan indikator pembelajaran untuk masing-masing pertemuan berdasarkan standar kompetensi, dan kompetensi dasar yang tercantum pada kurikulum tingkat satuan pendidikan (KTSP) untuk materi reaksi oksidasireduksi.

b) Menyusun Rencana Pelaksanaan Pembelajaran (RPP) kimia untuk pokok bahasan materi reaksi oksidasireduksi sesuai dengan sintak model pembelajaran generatif.

c) Mempersiapkan lembar kerja siswa (LKS) sesuai dengan sintak model pembelajaran generatif untuk materi reaksi oksidasi-reduksi.

d) Merancang instrumen penelitian seperti: lembar kerja siswa (LKS) dan tes ulangan harian II (pemahaman konsep).

e) Menyiapkan kunci jawaban

Data pemahaman konsep diperoleh berdasarkan tes pada akhir siklus II.
Sebaran frekuensi data pemahaman konsep siswa siklus II disajikan pada Tabel 6.

Tabel 6. Pemahaman konsep siswa siklus II

\begin{tabular}{ccccc}
\hline $\begin{array}{c}\text { Inter } \\
\text { val }\end{array}$ & $\begin{array}{c}\text { Batas } \\
\text { Bawah }\end{array}$ & $\begin{array}{c}\text { Batas } \\
\text { Atas }\end{array}$ & $\begin{array}{c}\text { Titik } \\
\text { Tengah }\end{array}$ & $\begin{array}{c}\text { Fre } \\
\text { kue } \\
\text { nsi }\end{array}$ \\
\hline $73-76$ & 72,5 & 76,5 & 74,5 & 2 \\
$77-80$ & 76,5 & 80,5 & 78,5 & 16 \\
$81-84$ & 80,5 & 84,5 & 82,5 & 0 \\
$85-88$ & 84,5 & 88,5 & 86,5 & 12 \\
$89-92$ & 88,5 & 92,5 & 90,5 & 0 \\
$93-96$ & 92,5 & 96,5 & 94,5 & 6 \\
\hline
\end{tabular}

Untuk mengetahui tingkat sebaran data pemahaman konsep siswa siklus II disajikan pada Gambar 3.

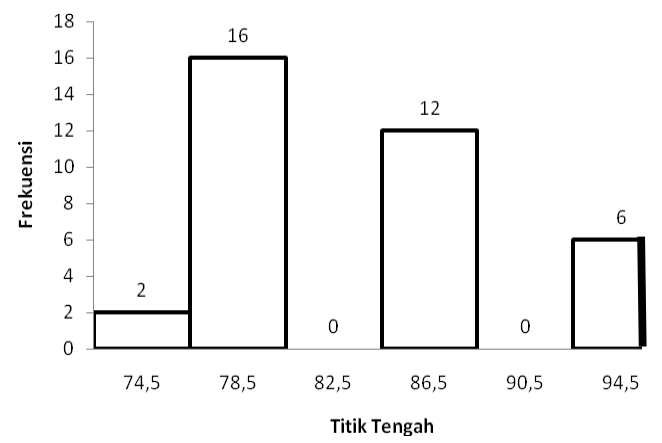

Gambar 3. Pemahaman konsep siswa siklus II

Persentase pemahaman konsep siswa pada akhir siklus II untuk masingmasing kategori berdasarkan 7 .

Tabel 7. Ketuntasan belajar siswa siklus II

\begin{tabular}{ccccc}
\hline $\begin{array}{c}\text { Katego } \\
\text { ri }\end{array}$ & $\begin{array}{c}\text { Jml } \\
\text { siswa }\end{array}$ & $\begin{array}{c}\text { Perse } \\
\text { ntase }\end{array}$ & DSS & KK \\
\hline Tuntas & 34 & $\begin{array}{c}94,44 \\
\%\end{array}$ & 84, & 94,4 \\
Tidak & 2 & $5,56 \%$ & $07 \%$ & $4 \%$ \\
Tuntas & 2 & & \\
\hline
\end{tabular}

Berdasarkan hasil analisis data pemahaman konsep siswa pada siklus II diperoleh rata-rata sebesar 84,07 dengan daya serap $84,07 \%$ dan standar deviasi 5,58 serta dengan tingkat ketuntasan klasikal sebesar 94,44\%. Kategori 
keberhasilan penelitian adalah jika nilai rata-rata siswa lebih besar atau sama dengan 75, daya serap siswa lebih besar atau sama dengan $75 \%$ dan ketuntasan klasikal siswa lebih besar atau sama dengan $85 \%$. Berdasarkan data nilai pemahaman konsep siswa pada siklus II, maka penelitian ini sudah memenuhi syarat keberhasilan tersebut. Hal ini karena berdasarkan kategori yang telah ditetapkan.

Data kinerja ilmiah merupakan akumulasi data kinerja ilmiah siswa setiap pertemuan siklus II. Tabel 8 menyajikan Data kinerja ilmiah siswa.

Tabel 8. Rekapitulasi Data Kinerja Ilmiah Siklus II

\begin{tabular}{ccc}
\hline No Uraian & Jumlah & Kualifikasi \\
\hline Rata-rata & 71,36 & \\
standar Deviasi & 10,89 & T \\
Skor max & 91 & \\
skor min & 54 & \\
\hline
\end{tabular}

Untuk melihat perkembangan kinerja ilmiah siswa dari pertemuan pertama sampai pertemuan ketiga berikut disajikan pencapaian kinerja ilmiah siswa siklus II seperti Tabel 9.

Tabel 9. Perbandingan rata-rata kinerja ilmiah siswa siklus II

\begin{tabular}{lccc}
\hline \multirow{2}{*}{ Variabel Data } & \multicolumn{3}{c}{ Pertemuan Siklus II } \\
& I & II & III \\
\hline Rata-rata & 61,11 & 71,57 & 81,39 \\
Standar Deviasi & 12,82 & 13,49 & 8,45 \\
Skor & 90 & 90 & 97 \\
Maksimum & & 50 & 70 \\
Skor Minimum & 43 & T & ST \\
Kualifikasi & CT & &
\end{tabular}

Untuk mengetahui kualifikasi data kinerja ilmiah siklus II disajikan pada Tabel 10.
Tabel 10. Kualifikasi Data Kinerja Ilmiah Siklus II

\begin{tabular}{|c|c|c|c|}
\hline Kriteria & Kategori & $\begin{array}{c}\text { Fre- } \\
\text { kuensi }\end{array}$ & $(\%)$ \\
\hline$X \geq 80$ & $\begin{array}{l}\text { Sangat } \\
\text { Tinggi }\end{array}$ & 10 & $27,78 \%$ \\
\hline $67 \geq X<80$ & $\begin{array}{l}\text { Tinggi } \\
\text { Cukup }\end{array}$ & 10 & $27,78 \%$ \\
\hline $53 \geq X<67$ & $\begin{array}{l}\text { Tinggi } \\
\text { Kurang }\end{array}$ & 16 & $44,44 \%$ \\
\hline $40 \geq X<53$ & $\begin{array}{l}\text { Tinggi } \\
\text { Sangat } \\
\text { Kurang }\end{array}$ & 0 & $0,00 \%$ \\
\hline$X<40$ & $\begin{array}{l}\text { Tinggi } \\
\text { ata-rata }\end{array}$ & 0 & $\begin{array}{c}0,00 \% \\
71,36\end{array}$ \\
\hline & ar Deviasi & & 10,89 \\
\hline Skc & Maksimum & & 91 \\
\hline & $\begin{array}{l}\text { Minimum } \\
\text { alifikasi }\end{array}$ & & $\begin{array}{c}54 \\
\text { Tinggi }\end{array}$ \\
\hline
\end{tabular}

Berdasarkan hasil analisis data kinerja ilmiah siswa, diperoleh rata-rata kinerja ilmiah siswa $\left(\overline{\mathrm{X}}_{k i}\right)$ sebesar 71,36 dengan standar deviasi 10,89. Berdasarkan kriteria penggolongan kinerja ilmiah siswa yang telah ditetapkan, kinerja ilmiah siswa kelas X C SMA Negeri 5 Denpasar pada siklus II berada pada kategori Tinggi.

Berdasarkan hasil penelitian yang dilaksanakan dalam dua siklus, menunjukkan telah terjadi peningkatan baik dari segi pemahaman konsep maupun kinerja ilmiah siswa.

Pemahaman konsep yang dimaksud dalam penelitian ini hasil belajar yang mencakup semua sub ranah dalam ranah kognitif kimia siswa. Data pemahaman konsep siswa dikontribusi dari tes pada tiap akhir siklus. Hasil penelitian pada siklus I menunjukkan nilai rata-rata pemahaman konsep siswa sebesar 76,30 dan ketuntasan klasikalnya $72,22 \%$. Daya serap siswa adalah sebesar 76,30\% dengan standar deviasi 7,88. Pada siklus I dilihat dari segi pemahaman konsep, siswa yang tuntas adalah sebanyak 24 orang dan yang tidak tuntas sebanyak 12 orang. Nilai ratarata pemahaman konsep siswa pada siklus 
I sudah mencapai kategori tuntas yaitu lebih besar dari 75. Meskipun demikian, pada siklus I ketuntasan klasikalnya masih di bawah $85 \%$, sehingga dapat dikatakan bahwa proses pembelajaran belum berhasil karena ketuntasan kalsikalnya masih berada pada kategori tidak tuntas.

Data kinerja ilmiah siswa dikumpulkan dengan menggunakan lembar observasi kinerja ilmiah yang terdiri dari 6 item penilaian yaitu dari segi perencanaan dan perancangan alat, penggunaan peralatan, pelaksanaan pengukuran, observasi dan pencatatan data, interpretasi data dan eksperimen, dan tanggung jawab/kebiasaan kerja/inisiatif. Masingmasing item tersebut terdiri atas lima kriteria dengan rentang skor 1 sampai 5 . Nilai kinerja ilmiah dikumpulkan setiap petemuan kecuali pada akhir siklus. Hasil analisis data menunjukkan nilai rata-rata kinerja ilmiah siswa pada siklus I adalah sebesar 52,56 dengan standar deviasi 14,76 yang berada pada kategori kurang tinggi. Berdasarkan pada data yang didapatkan pada refleksi awal, maka nilai rata-rata kinerja ilmiah siswa pada siklus I lebih tinggi dari nilai awalnya. Hal ini disebabkan ketika guru melakukan penilaian terhadap kinerja ilmiah, guru belum menggunakan rubrik yang sesuai. Penilaian terhadap kinerja ilmiah siswa dilakukan hanya sekali pada akhir tes semester dengan melihat keaktifan di kelas dan sikap siswa sehari-hari. Sehingga dapat dikatakan penilaian yang dilakukan terhadap kinerja ilmiah siswa kurang obyektif. Hal ini karena penilaian terhadap kinerja ilmiah siswa haruslah dilakukan dengan berpedoman pada rubrik yang sesuai dan didalamnya terdapat beberapa aspek dari kinerja ilmiah itu sendiri.
Berdasarkan kategori yang ditetapkan, maka kinerja ilmiah siswa pada siklus I berada di bawah kategori yang ditetapkan. Kinerja ilmiah siswa dikatakan behasil jika berada pada kategori tinggi. Dengan demikian, maka pada siklus I keberhasilan kinerja ilmiah siswa belum tercapai. Sehingga secara keseluruhan dapat dikatakan bahwa proses pembelajaran pada siklus I berada pada kategori tidak tuntas. Beberapa faktor yang disinyalir menyebabkan belum tuntasnya kegiatan pembelajaran pada siklus I telah dipaparkan pada hasil refleksi siklus I.

Pelaksanaan tindakan siklus II merupakan perbaikan dari pelaksanaan tindakan pada siklus I. Setelah dilakukan beberapa perbaikan pelaksanaan tindakan yang mengacu pada hasil refleksi siklus I, ternyata terjadi peningkatan baik dari segi pemahaman konsep maupun kinerja ilmiah siswa. Berdasarkan analisis data nilai ratarata pemahaman konsep pada siklus II sebesar 84,07 dengan ketuntasan klasikalnya mencapai $94,44 \%$. Daya serap siswa pada siklus II adalah sebesar 84,07\% dengan standar deviasi 5,58. Frekwensi siswa yang tuntas adalah sebanyak 34 orang dan yang tidak tuntas sebanyak 2 orang siswa. Hasil ini menunjukkan terjadi peningkatan daya serap siswa dalam pemhaman konsep dari siklus I ke siklus II sebesar 7,77\%. Berdasarkan hasil ini, maka ketuntasan kalsikal dan daya serap siswa pada siklus II ini sudah memenuhi ketentuan yang ditetapkan yaitu dengan daya serap lebih besar dari 75 dan ketuntasan klasikal lebih besar dari $85 \%$. Sehingga dari segi pemahaman konsep, maka dapat dikatakan penelitian ini sudah berada pada kategori berhasil. Sedangkan, nilai rata-rata kinerja ilmiah siswa pada siklus II didapatkan sebesar 71,36 dengan standar deviasi 10,89 yang berada pada 
kategori tinggi. Kinerja ilmiah siswa mengalami peningkatan dari siklus I ke siklus II sebesar $35,77 \%$. Hasil tersebut menunjukkan bahwa penerapan model pembelajaran generatif dengan setting kelas kooperatif Student Team Achievment Division (STAD) dapat meningkatkan pemahaman konsep dan kinerja ilmiah siswa.

\section{SIMPULAN}

Berdasarkan hasil analisis dan pembahasan, maka dapat disimpulkan halhal sebagai berikut.

1. Penerapan model pembelajaran generatif dengan seting kelas kooperatif STAD dapat meningkatkan pemahaman konsep kimia siswa kelas $X$ MIPA 7 SMA Negeri 5 Denpasar Tahun Ajaran 2016/2017. Hal ini terlihat dari nilai rata-rata pemahaman konsep siswa sebesar 76,30 dan ketuntasan klasikalnya $72,22 \%$. Daya serap siswa adalah sebesar $76,30 \%$ dengan standar deviasi 7,88 meningkat pada siklus II sebesar 84,07 dengan ketuntasan klasikalnya mencapai $94,44 \%$. Daya serap siswa pada siklus II adal ah sebesar $84,07 \%$ dengan standar deviasi 5,58.

2. Penerapan model pembelajaran generatif dengan seting kelas kooperatif STAD dapat meningkatkan kinerja ilmiah siswa kelas X MIPA 7 SMA Negeri 5 Denpasar Tahun Ajaran 2016/2017. Hal ini terlihat dari nilai rata-rata kinerja ilmiah siswa pada siklus I sebesar 52,56 dengan standar deviasi 14,76 yang berada pada kategori kurang tinggi meningkat pada siklus II menjadi 71,36 dengan standar deviasi 10,89 yang berada pada kategori tinggi. Kinerja ilmiah siswa mengalami peningkatan dari siklus I ke siklus II sebesar $35,77 \%$.

\section{DAFTAR PUSTAKA}

Arikunto. (2003). Management Penelitian. Jakarta: Rineka Cipta.

Mardana, I B., Suastra, I W., \& Artuti, N. (2001). Implementasi model pembelajaran generatif pada pembelajaran IPA yang berwawasan STM di SLTP se kota Singaraja. (Laporan Penelitian Dosen Muda). Institut Keguruan dan Ilmu Pendidikan Negeri Singaraja.

Nurkancana, W., \& Sunartana, P P.N. (1990). Evaluasi Hasil Pendidikan. Surabaya: Usaha Nasional.

Setiawan, I G A N. (2005). Pembelajaran kontekstual. (Makalah). Disampaikan dalam lokakarya model-model pembelajaran inovatif program kemitraan jurusan Pendidikan Biologi IKIP Negeri Singaraja dan SMA Negeri 1 Singaraja pada tangal 19 dan 20 juli 2005.

Suastra, I W. (2006). Belajar dan pembelajaran sains. Buku Ajar. Jurusan Pendidikan Fisika Universitas Pendidikan Ganesha Singaraja.

Sugiarta, I M. (2003). Inovasi model pembelajaran generatif dengan metode pq4r berbantuan modul dalam perkuliahan statistika dasar. (Laporan Hibah Pengajaran). Jurusan Pendidikan Matematika. Institut Keguruan dan Ilmu Pendidikan Negeri Singaraja.

Tika, I K. (2005). Pengaruh model belajar terhadap hasil belajar dan konsep diri dalam pembelajaran fisika pada siswa kelas III SMP. Tesis (tidak diterbitkan). Program Pasca Sarjana; Institut Keguruan dan Ilmu Pendidikan Negeri Singaraja.

Triatno. (2007). Model-model pembelajaran inovatif berorientasi konstruktivistik. Jakarta: Prestasi Pustaka Publisher. 